\title{
Safe surgery checklist: content validation proposal for liver transplantation
}

\author{
Lista de verificação de cirurgia segura: proposta de validação de conteúdo para o transplante hepático \\ Lista de verificación de cirugía segura: propuesta de validación de contenido para trasplante de hígado
}

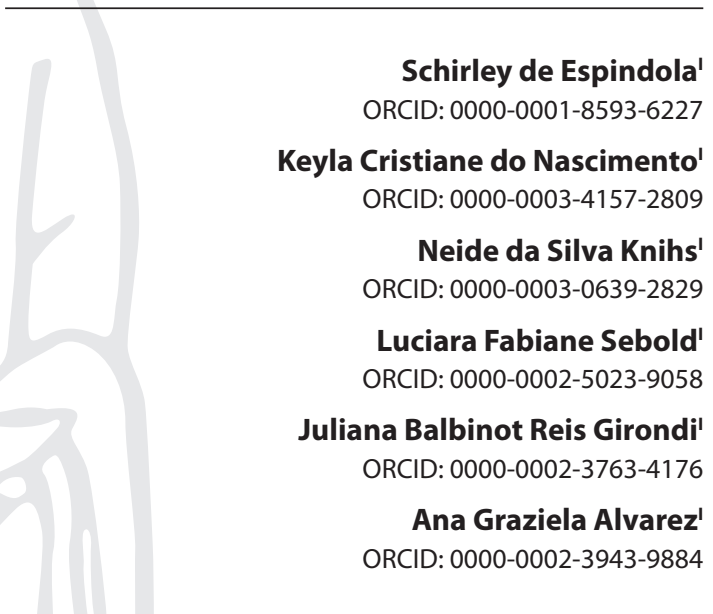

'Universidade Federal de Santa Catarina. Florianópolis, Santa Catarina, Brazil.

How to cite this article: Espindola S, Nascimento KC, Knihs NS, Sebold LF, Girondi JBR, Alvarez AG. Safe surgery checklist: content validation proposal for liver transplantation. Rev Bras Enferm. 2020;73(Suppl 6):e20190538. doi: http://dx.doi.org/10.1590/0034-7167-2019-0538

\section{Corresponding author: \\ Schirley de Espindola \\ E-mail: schirley_1995@hotmail.com}

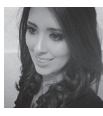

EDITOR IN CHIEF: Antonio José de Almeida Filho ASSOCIATE EDITOR: Alexandre Balsanelli

Submission: 09-25-2019 Approval: 05-11-2020

\begin{abstract}
Objectives: to develop the safe surgery checklist for liver transplantation according to the original model of the World Health Organization and perform content validation. Methods: a methodological research developed in four stages: integrative review; expert participation; consensus among researchers; and content validation using the Delphi technique in two rounds, by five judges. For data analysis, the Content Validation Index was used. Results: the first version of the checklist consisted of four surgical moments with 64 items of verification, with an average Content Validation Index of 0.80 . After adjustments, in the second round the checklist maintained four surgical moments with 76 items and a Content Validation Index of 0.87 . Conclusions: the checklist was validated and adequate for the safety of liver transplantation in the surgical environment, given that each item established must be mapped and managed for the success and effectiveness of the procedure.

Descriptors: Perioperative Nursing; Intraoperative Period; Liver Transplantation; Patient Safety; Checklist.
\end{abstract}

\section{RESUMO}

Objetivos: elaborar a lista de verificação de cirurgia segura para transplante hepático segundo modelo original da Organização Mundial da Saúde e realizar a validação de conteúdo. Métodos: pesquisa metodológica desenvolvida em quatro etapas: revisão integrativa; participação de experts; consenso entre os pesquisadores; e validação de conteúdo utilizando a técnica Delphi em duas rodadas, por cinco juízes. Para análise dos dados, foi utilizado o Índice de Validação de Conteúdo. Resultados: a primeira versão do checklist foi formada por quatro momentos cirúrgicos com 64 itens de verificação, com média do Índice de Validação de Conteúdo de 0,80. Após ajustes, na segunda rodada o checklist manteve quatro momentos cirúrgicos com 76 itens e Índice de Validação de Conteúdo de 0,87 . Conclusões: considerouse o checklist validado e adequado para segurança do transplante hepático no ambiente cirúrgico, haja vista que cada item estabelecido deve ser mapeado e gerenciado para o sucesso e efetividade no procedimento.

Descritores: Enfermagem Perioperatória; Período Intraoperatório; Transplante de Fígado; Segurança do Paciente; Lista de Checagem.

\section{RESUMEN}

Objetivos: elaborar la lista de verificación de cirugía segura para trasplante hepático según modelo original de la Organización Mundial de la Salud y realizar la validación de contenido. Métodos: investigación metodológica desarrollada en cuatro etapas: revisión integrativa; participación de especialistas; consenso entre los investigadores; y validación de contenido utilizando la técnica Delphi en dos rodadas, por cinco jueces. Para análisis de los datos, ha sido utilizado el Índice de Validación de Contenido. Resultados: la primera versión del checklist ha sido formada por cuatro momentos quirúrgicos con 64 ítems de verificación, con media del Índice de Validación de Contenido de 0,80. Después de ajustes, en la segunda rodada el checklist mantuvo cuatro momentos quirúrgicos con 76 ítems e Índice de Validación de Contenido de 0,87 . Conclusiones: se ha considerado el checklist validado y adecuado para seguridad del trasplante hepático en el ambiente quirúrgico, puesto que cada ítem establecido debe ser mapeado y administrado para el suceso y efectividad en el procedimiento. Descriptores: Enfermería Perioperatoria; Período Intraoperatorio; Trasplante Hepático; Seguridad del Paciente; Lista de Control. 
Safe surgery checklist: content validation proposal for liver transplantation Espindola S, Nascimento KC, Knihs NS, Sebold LF, Girondi JBR, Alvarez AG.

\section{INTRODUCTION}

A checklist is an instrument used for quick and simple checks, and should be used by all professionals in the health team, as it enables safer care practices, minimizing risks in patient care, besides reducing hospitalization time, risk of failures, hospital expenses and improved communication between professionals $\mathbf{s}^{(1-4)}$.

To promote safe surgery, the World Health Organization (WHO) has prepared a checklist — validated for Brazil and called a checklist - which establishes three phases: the first, called Sign in, which occurs before induction of anesthesia; the second, Time out, performed immediately before the surgical incision; and the third, Sign out, developed before the patient left the operating room. This instrument aims to meet a central set of safety standards, increasing the quality of the service, preventing sentinel events, surgical site infections, enabling safe anesthesia, safe surgical teams ${ }^{(1-4)}$.

It is a multi-professional tool, flexible, being possible to adapt it to each reality. It should be adjusted according to the need of the institution and focused on the complexity of the surgical procedure so that it can contribute to the excellence of patient care $^{(1,4-5)}$

Among the various complex procedures developed in the surgical environment, liver transplantation (Liver Transplant) is considered an extremely complex surgery, considering: the importance of the liver as a vital organ of the organism and its influence on the patient's hemodynamic stability; surgical time; the presence of the anepathic phase; and factors related to the graft. It is worth noting that this procedure consists of the total removal of the diseased liver and the replacement of a healthy liver, with the anatomical reconstruction of the liver and the biliary tract as close to the physiological pattern as possible ${ }^{(6-8)}$.

Still, from the perspective of this surgery, the need to manage donor-related data (age, blood type, time of aortic clamping, organ perfusion conditions, ischemia time) and the recipient (age, blood type, pre-Liver Transplant exams, among others) ${ }^{(9)}$. The National Health Surveillance Agency (ANVISA) ${ }^{(10)}$, through bio-vigilance, determines the management and monitoring of information from the selection of the donor to the extraction, preparation, conservation, control, distribution and implantation of the organ. Thus, it aims to develop a safe procedure in order to provide better quality of life for the patient and graft survival(10).

As a result, it is understood as necessary and prudent to constantly manage and evaluate the conduct of the Liver Transplant surgical procedure through the checklist adjusted for such surgical reality. In order to provide greater safety during the operation, quality of care provided and less chance of errors and adverse events (AE) arising in the Liver Transplant procedure in adults, the guiding question of this study is: What are the items to be adjusted and included in the WHO safe surgery checklist for the liver transplant surgical procedure in adult patients?

\section{OBJECTIVES}

To develop the safe surgery checklist for liver transplantation according to the original model of the World Health Organization and perform content validation.

\section{METHODS}

\section{Ethical aspects}

This research complied with the terms of Resolution $466 \mathrm{NHC} /$ $\mathrm{MH}$, of December 12, 2012, which regulates and regulates research with human beings; and was approved by the Research Ethics Committee of the Federal University of Santa Catarina (UFSC), under Opinion No. 2.17.221.

\section{Design and period}

This is a methodological, quantitative study, whose purpose was to promote adjustments to the WHO safe surgery checklist for the liver transplantation surgical procedure in adult patients. The choice for adult patients is related to the fact that this procedure in children has other specific characteristics, which requires new adjustments in the tool. The study was developed in four stages, carried out from April to July 2017, being presented below. Content validation took place from August to November of the same year.

\section{Study location}

Teaching hospital in the southern region of Brazil, linked to a public university of reference in the Liver Transplant procedure since 2011. Until 2018, more than 120 procedures related to liver transplantation were performed there.

\section{Population, inclusion and exclusion criteria}

The population to assess the preliminary checklist for clarity (must be easy to understand or understand) and pertinence (must be congruent and relevant to the theme). Criteria for inclusion of professionals with expertise who participated in the second stage of the research: training time in the health field over eight years and time in the Liver Transplant transoperative area over five years. To define these criteria, the authors considered the complexity and specificities of the Liver Transplant transoperative, as already mentioned. Seven professionals participated, among them: anesthetists, nurses and surgeons of Liver Transplant.

After necessary adjustments to the checklist as suggested by professionals with expertise, the content was validated with the participation of five judges. To define them, the following criteria were used: having a degree in Nursing or Medicine; masters and / or doctorate; have published works in the area of interest of the study; have at least five years' experience in direct Liver Transplant patient care during the operation. The search for the judges took place in June and July 2017 through the curriculum at Lattes Platform - National Council for Scientific and Technological Development (CNPq). The sample of judges was intentional, considering those who met the largest number of criteria established. Contacts with them were made via e-mail, to send the FICT as well as documents and guidelines in order to proceed with content validation.

\section{Study protocol}

The construction of the checklist consisted of four distinct stages: 1) an integrative literature review, 2) consultation with 
professionals with expertise in the field, 3) preparation of the first version of the safe surgery checklist adapted for Liver Transplant and 4) content validation performed using the Delphi technique.

1 st step - Literature review through six stages: elaboration of the research question; definition of criteria for searching the literature; data collection; critical analysis of the material obtained; careful evaluation and interpretation of information; and presentation of the results obtained. The search was carried out in six databases, namely, Latin American and Caribbean Literature in Health Sciences (LILACS), Biomedical Literature Citations and Abstracts (PubMed), SCOPUS, Web of Science and Cumulative Index to Nursing and Allied Health Literature (CINAHL) and the Scientific Electronic Library Online library (SciELO); without time filter, in order to find as much information as possible. The literature search aimed to identify evidence regarding safety in the Liver Transplant transoperative that supported adjustments and inclusion of items in the WHO checklist (original version). It was carried out by two independent professionals between April and May 2017. The search strategy was subsidized by a librarian, who used the descriptors "intraoperative period", "surgical centers", "liver transplantation","safety management","safety", "patient safety" and "checklist", in Portuguese, English and Spanish, without restriction of years. In this review, 16 articles related to the theme were identified. However, only four referred to safe care during LiverTransplant transoperative. The information obtained in the integrative review was organized in an electronic spreadsheet with the aid of Excel software version 2013, in which they were recorded: title, year of publication, authors, journal, database, objectives, type of study, level of evidence, results and recommendations.

2nd step - Considering the little material obtained in the literature review to compose the adjustments in the checklist, professionals with expertise in the area and who could contribute with other information related to the Liver Transplant transoperative were sought. An anesthetist, a nurse and a Liver Transplant surgeon participated in this step. To obtain their contributions, there were two meetings, in which the WHO checklist (original version) and the data obtained from the literature review were presented. Contributions were guided through the three phases of the WHO checklist (Sign in, Time out, Sign out). Following, they were asked to point out important issues and facts about Liver Transplant that needed management and care by the surgical team.

3rd step - After meeting with the experts, the researchers met to define the items to be adjusted and included in the WHO checklist (original version), thus composing the first version of the checklist adapted for Liver Transplant, formed by four surgical moments with 64 items. To minimize the risk of bias, three researchers were present, with two 30-minute meetings. It is noted that one of the researchers has 16 years of experience in Liver Transplant.

4th step -Validation of the content of the checklist, performed using the Delphi technique, with the participation of five judges, in two cycles. The Delphi technique was chosen because it is a method intended to deduce and refine the opinions of a group of people, experts/judges, researchers with experience in validation. In this method, a systematic search is made to carefully evaluate each item of the instrument through two rounds. In view of the need to promote systematic and refined adjustments to the Liver Transplant safe surgery checklist, the researchers consider this method promising to support the development of validation. This reference does not define the number of specialists / experts, but determines that they must be chosen according to their competence in the area, experience in the subject, language and culture $^{(11)}$. Thus, this method was chosen due to the importance of the judges' experience in the Liver Transplant scenario.

In this study, consensus was defined as a Content Validity Index (CVI) greater than 0.8 in each item; if one of the items obtained a lower value, it would be excluded. The initial contact with the judges took place via e-mail, and later contact was made by telephone. The following documents were sent to them: WHO checklist (original version); first version of the checklist for the Liver Transplant and a table with all the items in it, in which there was space for them to score each item considering: clarity of language, content of the text, consistency of the item, relation of the item to its disposition in the checklist according to the WHO original. To score the items, the judges used the Likert scale with the following scores: 1 - strongly disagree; 2 - partially disagree; and 3 - strongly agree. When scoring scores 1 and 2 , they should point out their suggestions. The first round was carried out containing all the items on the checklist, so that they could be evaluated. After returning material from the first round, the adjustments requested by the judges were all made, obtaining the second version, which was sent for the second round of evaluations. At the end of the second round, the last adjustments were made, reaching the final version of the checklist for Liver Transplant.

\section{Analysis of results and statistics}

For the organization and analysis of literature evidence and data obtained from experts in the practice, the researchers read and reread the findings, carefully interpreting each fact and giving meaning to the material acquired according to each phase of the WHO checklist (original version): Sign in, Time out, Sign out. After analysis, adjustments were made to the original WHO version according to the most important recommendations that could support the first version of the checklist for Liver Transplant, considering the particularities of this procedure.

As for the organization and analysis of content validation, the data for each cycle were digitized in an Excel spreadsheet and analyzed using the calculation of the CVI, mean and standard deviation. The results are presented in descriptive form, graphs and tables, using the relative frequencies (\%) and the absolute frequency $(\mathrm{N})$ of the classes of each variable.

To better represent the $\mathrm{CVI}$, the items were grouped according to the surgical moments proposed by the WHO checklist (original version): Moment 1, items related to the activities "Before anesthetic induction"; Moment 2, the items related to "Before starting the surgery"; Moment 3, which was added to the checklist for Liver Transplant, considering that there are important data to be checked during the operation itself, and called "During the surgical procedure"; and Moment 4, formed by the items referring to "Before the patient leaves the operating room".

\section{RESULTS}

The results are presented using tables, tables and figures. Chart 1 presents examples of information obtained from evidence in the literature and from experts in practice, with the adjustments 
and inclusion of items pointed out by the judges. Tables 1 and 2, on the other hand, present the results of content validation by calculating the CVl; and Figure 1 shows the final version of the checklist for Liver Transplant.

In the first version of the checklist adjusted for Liver Transplant, consisting of four surgical moments, seven items were added at the time "Before anesthetic induction"; at the moment "Before starting the surgery", 26 items were added and/or adjusted; for the moment "During the surgical procedure", seven items were created; and at the time "Before the patient leaves the operating room", three items were added to the checklist.

Regarding the results of the content validation, it is noted that all the judges have expertise in the Liver Transplant area; everyone participates directly in Liver Transplant, three of them directly in care during the operation and two of them in research in the Liver Transplant scenario. Table 1 shows the results of the CVI of the first version of the Liver Transplant checklist.

Table 1 - Mean Content Validity Index, mean and standard deviation per surgical moment of the first round of validation of the Liver Transplant checklist, Florianópolis, Santa Catarina, Brazil, 2019

\begin{tabular}{lccc}
\hline Surgical moment & CVI & Average & $\begin{array}{c}\text { Standard } \\
\text { deviation }\end{array}$ \\
\hline Before anesthetic induction & 0.66 & 2.56 & 0.52 \\
Before starting surgery & 0.89 & 2.88 & 0.18 \\
During the surgical procedure & 0.78 & 2.72 & 0.37 \\
Before the patient leaves the operating room & 0.87 & 2.85 & 0.33 \\
Overall average of categories & 0.80 & 2.75 & 0.35 \\
\hline
\end{tabular}

Note: CVI-Content Validity Index.

It is noteworthy that all the suggestions proposed by the judges in the first round were made. For further clarification of these adjustments, Chart 1 shows, as an example, the changes made at the surgical moment "Before starting the surgery" in the checklist for Liver Transplant. We chose to present this category because it was the one that suffered the greatest adjustments and inclusion.

Chart 1 - Modifications, changes and / or adjustments (A) and inclusion (I) of items by the judges at the surgical moment "Before starting the surgery", second version in the Liver Transplant checklist, Florianópolis, Santa Catarina, Brazil, 2019

Second version after adjustments and inclusion of items by the judges

\section{Adjustment (A):}

Check heating system installation;

Check puncture of two peripheral accesses;

Maintain body temperature above $36^{\circ} \mathrm{C}$

Inclusion(I)

Installation of transesophageal echo;

Check transplant modality;

Check installation of nasogastric tube;

Check installation of thrombus prevention device;

Check volume expanders (crystalloid / colloid);

Check auto-transfusion system;

Check installation of rapid infusion device;

Check installation of coagulation control device.

After adjustments made to the four phases of the Liver Transplant checklist, the second version was sent to the judges for the second round of evaluation. However, it was pointed out to them that they should evaluate only the changed items, according to suggestions and inclusions. Considering the CVI of the second round, Table 2 shows that the highest CVI value is at the moment "During the surgical procedure", 0.92, with the general average of the surgical moments being 0.87 ; standard deviation of 0.22 .

Table 2 - Mean Content Validity Index, mean and standard deviation per surgical moment of the second round of validation of the Liver Transplant checklist, Florianópolis, Santa Catarina, Brazil, 2019

\begin{tabular}{lccc}
\hline Surgical moment & CVI & Average & $\begin{array}{c}\text { Standard } \\
\text { deviation }\end{array}$ \\
\hline Before anesthetic induction & 0.89 & 2.82 & 0.13 \\
Before starting surgery & 0.84 & 2.82 & 0.28 \\
During the surgical procedure & 0.92 & 2.92 & 0.14 \\
Before the patient leaves the operating room & 0.83 & 2.83 & 0.33 \\
Overall average & 0.87 & 2.84 & 0.22 \\
\hline Note: $C V I$ - Content Validity Index. & & &
\end{tabular}

The following is the final version of the Liver Transplant safe surgery checklist.

\section{DISCUSSION}

In this study, the development of the adjustments in the safe surgery checklist sought to meet the specific needs of the Liver Transplant transoperative. During the progress of each stage, we sought to include evidence from the literature, suggestions from experts, as well as changes presented by the judges in order to ensure a tool that supports the multidisciplinary team in the safety of this procedure. Above all, this tool addresses the requirements of ANVISA through bio-surveillance ${ }^{(10)}$, providing, in the postoperative period, better graft functionality and restoration of the functional activity of the liver and the patient ${ }^{(7-8,12-15)}$.

As for the evidence in the literature, there were few suggestions for changes in the tool: the data practically points to body temperature, surgical position and use of blood products ${ }^{(12-15)}$. The information of professionals with expertise in the area, on the other hand, gave rise to important facts to be checked by the team at all stages of the checklist. The combination of such identified facts, after the researchers' analysis, enabled the first version of the checklist for Liver Transplant, with 64 verification items. The surgical moment in which there were more adjustments and inclusion of items was, "Before starting the surgery"; both for the evidence, for the professionals with expertise, as well as for the judges in the content validation.

All the surgical moments presented in the checklist are extremely important; however, the phases "Before anesthetic induction" and "Before starting surgery" are unique moments in this procedure, considering that many patients, when undergoing Liver Transplant, will have their first contact with the surgical team on arrival at the surgical environment. When judging that Liver Transplant surgery, in many situations, due to the severity of the patient and factors related to logistics, occurs at an unscheduled and/or scheduled time in advance, there is a possibility that the team responsible for conducting the stages of the operation has not had previous contact with the patient.

From this perspective, the Liver Transplant checklist tends to promote safety when investigating the patient's name, the modality of $\mathrm{TH}$, factors related to blood products, biochemistry exams 


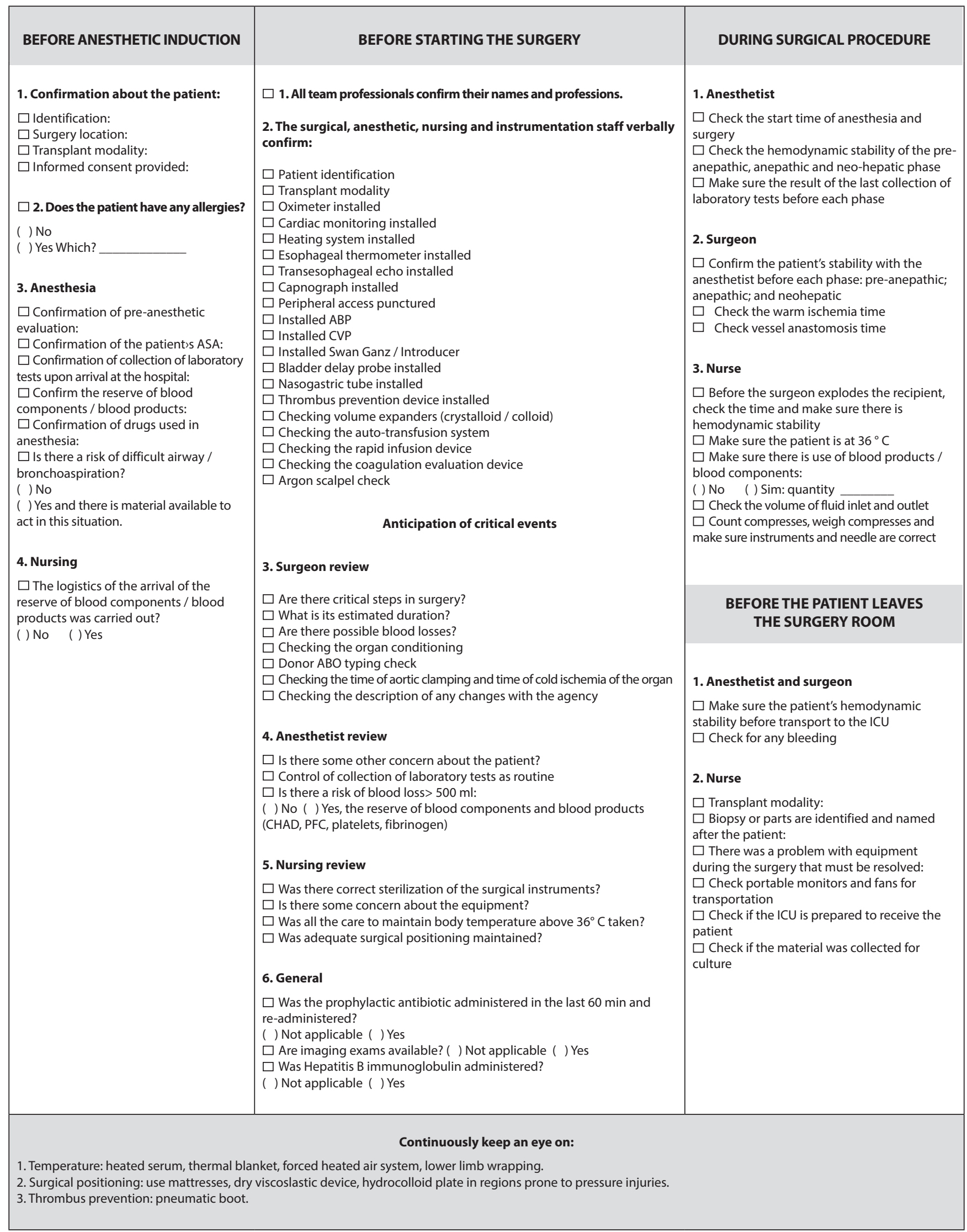

Figure 1 - Safe surgery checklist for liver transplantation, Florianópolis, Santa Catarina, Brazil, 2019 
and pre-anesthetic consultation. Studies indicate the verification of laboratory tests as a safety criterion in anesthetic induction, making it possible to take actions as soon as possible to reverse certain problems ${ }^{(16-17)}$. In liver transplantation, anesthetic induction ensures a stable transoperative, a more peaceful anepathic and neohepatic phase, in addition to an effective reperfusion considering the control performed by the anesthesiologist ${ }^{(18-20)}$.

With regard to checking, the moment "Before starting the surgery", which underwent the greatest number of adjustments and inclusion of items, the evidence brought data related to body temperature and use of devices ${ }^{(12-15)}$. The professionals with expertise highlighted factors related to the donor and recipient, items related to rapid infusion and care for the prevention of complications such as pressure injury and thrombosis. Such care is fundamental to the Liver Transplant procedure, providing safety and preventing major health complications in this postoperative period ${ }^{(21-22)}$.

Still, with regard to such surgical moment, it is noteworthy that the greatest number of items inclusion is directed to the use of devices, whose relationship with safety in the Liver Transplant procedure involves hemodynamic monitoring, quality in the procedure, less risk of damage and injuries in the postoperative period, in addition to strict control of cardiac, pulmonary and renal functions, among others ${ }^{(23)}$.

Bearing in mind that the Liver Transplant surgery time is prolonged, between six and ten hours, considering the effects of anesthesia on respiratory mechanics, lung volumes and gas exchange, in addition to the effects of the anepathic and neohepatic phase in the body, the devices allow monitoring of hemodynamics and help to assess and assume appropriate and immediate procedures preventing risk and damage to the patient ${ }^{(24-26)}$. The use of devices and equipment in Liver Transplant are extremely important to promote agility and safety during the operation ${ }^{(16-17,20)}$. There are recommendations that, in major surgeries, devices should be installed, as well as maintaining a temperature above $36^{\circ} \mathrm{C}$ to promote hemodynamic stability ${ }^{(27)}$.

The inclusion of a third check category, called "During the surgical procedure", brings to the Liver Transplant checklist greater clarity and organization of the operative moments of this procedure, considering that transplants present a unique moment, referring to the removal of the diseased organ for implantation of the donor's organ. In Liver Transplant, this moment includes the so-called anepathic and neohepatic phases. In the anepathic phase, for a few minutes, the patient is left without the liver; and in the neo-hepatic phase, the donor liver starts to function - reperfusion occurs. These are crucial moments for the success of Liver Transplant, which requires the team to check important factors such as: hemodynamic stability for clinical maintenance, evaluation of the latest biochemical exams, in addition to stability for reperfusion of the new organ ${ }^{(18-19)}$.

The safety of the category "During the surgical procedure" is associated with heart rate control; reduction of central venous pressure; hemodynamic response to clamping of the inferior vena cava; substantial increase in the systemic vascular resistance index after clamping, showing weaker cardiovascular reflexes for reperfusion ${ }^{(18-19)}$. Thus, the inclusion of this category in the checklist for Liver Transplant implies the team's opportunity to manage, map and control factors related to important moments of this surgery as proposed by ANVISA through biovigilance ${ }^{(10)}$.

Regarding the safety of this procedure, the category "Before the patient leaves the operating room" on the Liver Transplant checklist proposed: adjustments directed to the verification and confirmation of equipment that can propose safety in transporting the patient from the surgical environment to the Intensive Care Unit (ICU); as well as the adjustments related to the checking of hemodynamic stability and complications that may compromise their arrival at the ICU. The checking of these items at the end of the surgery provides early extubation, which can also occur in the operating room, and minimizes the risk of cardiac arrhythmias, postoperative infections and cardiopulmonary arrest during the journey to the ICU (12-15,28).

Regarding the CVI values in content validation by judges, both in the first and second rounds, it is considered that there were satisfactory indexes, considering that 76 items were adjusted and included in the second version of the checklist for Liver Transplant, given that the lowest CVI index in the first round was 0.66 . In the second round, the lowest CVI was 0.83 . In two studies with checklist validation, in the first round, an agreement index between $60 \%$ and $100 \%$ was obtained ${ }^{(29-30)}$. This study does not differ from the others in relation to the CVI values found in the content validation stages, with the general CVI average in the first round being 0.8 , while in the second round, the average was 0.87 .

From this perspective, it is considered that content validation was extremely relevant for the creation of a safe surgery checklist for liver transplantation, since the judges, forming a multidisciplinary team, collaborated with adjustments and inclusion of important items, which will ensure a safer and more effective Liver Transplant procedure during the operation. In addition, this tool will assist in the communication between professionals involved in such surgery.

As this is a complex procedure and involves odd moments, causing tension in the team and can lead to failures and errors in the process, this tool appears as a support in the management of activities to be developed in the surgical environment. The secure exchange of essential information by the team while conducting the surgical procedure reinforces safety and supports the management of health actions ${ }^{(28,31-32)}$.

The results of this study, presented by adjusting the checklist, reveal the impact that this tool may have on the health services that perform Liver Transplant, in view of the complexity of this procedure and the demand for items to be verified. Such information corroborates a study in which the authors point out that, although this tool is a relatively simple strategy, the results are surprising in preventing adverse events, risk detection, reduction of surgical complications and effectiveness in the communication of the operational team ${ }^{(33)}$.

\section{Study limitations}

A limiting factor of this study is the failure to perform the clinical validation of the Liver Transplant checklist in the clinical practice of the intraoperative period. Another limitation was the difficulty in identifying professionals with expertise in the area according to inclusion criteria for participation in the study. 


\section{Contributions to the area of Nursing, Health or Public Policy}

It is understood that the process of preparing and validating the safe surgery checklist for liver transplantation brings important contributions to the safety of the Liver Transplant procedure during the operation, especially for nurses working in this area, since, in most cases, they have already participated in the donor's explant and are under strong impact from many hours of work, with several items to be checked. This checklist appears as support for these professionals in order to guide and guide in this procedure, considering that it has several stages during the operation and, when considering that the nurse manages all of them, this tool proposes speed, greater team skill, logical sequence and, above all, error prevention.

\section{CONCLUSIONS}

The purpose of this study was to present the checklist of safe surgery for liver transplantation adjusted based on the original version created by the WHO. It is noteworthy that this activity was successfully developed by exposing the checklist for Liver Transplant, composed of four surgical moments with 76 items to be checked. The four surgical moments (Before anesthetic induction, Before starting the surgery, During the surgical procedure and Before the patient leaves the operating room) present important factors for the safety of the Liver Transplant procedure in the surgical environment. Each item contains unique and necessary data to be mapped and managed in order to achieve success and effectiveness in Liver Transplant.

Regarding the content validation by the judges, it is considered that the Liver Transplant checklist was validated with excellence, since it obtained a CVI of 0.8 in the first round; and 0.87 in the second. It is concluded that the Liver Transplant safe surgery checklist proved to be valid, and its applicability may contribute to patient safety, since the tool aims to improve the quality of care, reduce adverse events and develop a culture of safety in the surgical environment.

\section{REFERENCES}

1. Agência Nacional de Vigilância Sanitária. Cirurgias Seguras Salvam Vidas [Internet]. 2009 [cited 2019 Jul 06];1:1-34. Available from: http:// bvsms.saude.gov.br/bvs/publicacoes/seguranca_paciente_cirurgias_seguras_guia.pdf

2. Diego LAS, Salman FC, Silva JH, Brandão JC, Oliveira-Filho G, Carneiro AF, et al. Construction of a tool to measure perceptions about the use of the World Health Organization Safe Surgery Checklist Program. Rev Bras Anestesiol. 2016;66(4):351-355. doi: 0.1016/j.bjane.2014.11.011

3. Santos JS, Souza DO, Morais AC, Santana CLM, Rodrigues US, Rodrigues EP.[ Test check pilot list of safe surgery: experience report]. Rev Enferm UFPI [Internet]. 2017 [cited 2019 Jul 06];6(1):76-79. Available from: http://ojs.ufpi.br/index.php/reufpi/article/view/5648/pdf Portuguese.

4. Peixoto SKR, Pereira BM, Silva LCS. [Checklist for safe surgery: a way to patient safety]. Saúde Ciência Ação [Internet]. 2016 [cited 2019 Jul 06];2(1):114-29. Available from: http://revistas.unifan.edu.br/index.php/RevistalCS/article/view/203/149 Portuguese.

5. Roscani ANCP, Ferraz EM, Oliveira-Filho AG, Freitas MIP. Validation of surgical checklist to prevent surgical site infection. Acta Paul Enferm. 2015;28(6):553-65. doi: 10.1590/1982-0194201500092

6. Ribeiro-Jr MAF, Medrado MB, Rosa OM, Silva AJD, Fontana MP, Cruvinel-Neto J, et al. Liver transplantation after severe hepatic trauma: current indications and results. ABCD Arq Bras Cir Dig. 2015;28(4):286-9. doi: 10.1590/s0102-6720201500040017

7. Mendes KD, Lopes NLC, Fabris MA, Castro-e-Silva OJ, Galvão CM. Sociodemographic and clinical characteristics of candidates for liver transplantation. Acta Paul Enferm. 2016;29(2):128-35. doi: 10.1590/1982-0194201600019

8. Araujo MPS, Oliveira AC. [What changes may occur in surgical care after the implementation of patient safety centers?]. Rev Enferm Cent $\mathrm{O}$ Min [Internet]. 2015 [cited 2019 Jul 06];5(1):1542-1551. Available from: http://www.seer.ufsj.edu.br/index.php/recom/article/view/807/844 Portuguese.

9. Presidência da República (BR). Decreto n. 9.175, de outubro de 2017: regulamenta a Lei n. 9.434, sancionada em 4 de fevereiro de 1997, para tratar da disposição de órgãos, tecidos, células e partes do corpo humano para fins de transplante e tratamento[Internet]. Diário Oficial da União; 2017[cited 2019 Jul 06]. Available from: https://presrepublica.jusbrasil2.com.br/legislacao/511312696/decreto-9175-17

10. Agência Nacional de Vigilância Sanitária (BR). Guia de Biovigilância de Células, Tecidos e Órgãos \& Manual de Notificação [Internet]. Brasília; 2016 [citado 2019 May 31]. Available from: http://portal.anvisa.gov.br/documents/33868/3055469/Guia+de+Biovig il\%C3\%A2ncia+de+C\%C3\%A9lulas\%2C+Tecidos+e+\%C3\%93rg\%C3\%A3os+\%26+Manual+de+Notifica\%C3\%A7\%C3\%A3o/ bfe1f75d-4351-4ca9-b56d-54c985213154

11. Castro AV, Rezende M. [The Delphi technique and its use in brazilian nursing research: bibliographical review]. Rev Min Enferm. 2009. 13(3):429-434. doi: S1415-27622009000300016 Portuguese.

12. Rocca DG, Flaviis AD, Costa MG, Chiarandini P, Pompei L, Venettoni S. Liver Transplant Quality and Safety Plan in Anesthesia and Intensive Care Medicine. Transplant Proc. 2010;42(6):2229-32. doi: 10.1016/j.transproceed.2010.05.043

13. Massicotte L, Beaulieu D, Thibeault L, Roy JD, Marleau D, Lapointe R, et al. Coagulation defects do not predict blood product requirements during liver transplantation. Transplant. 2008;85(7):956-962. doi: 10.1097/TP.0b013e318168fcd4

14. Neelakanta G, Colquhoun S, Csete M, Koroleff D, Mahajan A, Busuttil R. Efficacy and safety of heat exchanger added to venovenous bypass circuit during orthotopic liver transplantation. Transplant Surg. 1998;4(6):506-509. doi: 10.1002/lt.500040610 
15. Russell SH, Freeman JW. Comparison of bladder, oesophageal and pulmonary artery temperatures in major abdominal surgery. Anaesthesia. 1996;51(4):338-40. doi: 10.1111/j.1365-2044.1996.tb07743.x

16. Muniz RV, Bohrer BBA, Muhazzani MP, Erig LS, Santos SM, Santos HB. [Development and improvement of a surgical safety checklist for ophthalmological procedures]. Rev ACRED [Internet]. 2015 [cited 2019 Jul 06];5(9):85-101. Available from: https://dialnet.unirioja.es/ descarga/articulo/5626618.pdf Portuguese.

17. Studart RMB, Melo EM, Silva SLA, Santos AKL, Oliveira ANM, Falcão PV, et al. Patient safety evaluation during the anesthetic-surgical procedure. Rev Enferm UFPE. 2017;11(5):2195-201. doi: 10.5205/reuol.9302-81402-1-RV.1105sup201725

18. Siniscalchi A, Gamberini L, Laici C, Bardi T, Ercolani G, Lorenzini L, et al. Post reperfusion syndrome during liver transplantation: from pathophysiology to therapy and preventive strategies. World J. Gastroenterol. 2016;22(4):1551-1569. doi: 10.3748/wjg.v22.i4.1551

19. Jeong SM. Postreperfusion syndrome during liver transplantation. Korean J Anesthesiol. 12015;68(6):527-539. doi: 10.4097/ kjae.2015.68.6.527

20. Eiras FRC, Barbosa AP, Leão ER, Biancolino CA. Use of a severity indicator as a predictor of the use of hepatic transplantation resources. Rev Esc Enferm USP. 2016;50(4):578-84. doi: 10.1590/S0080-623420160000500006

21. Negreiros FDS, Pequeno AMC, Garcia JHP, Aguiar MIF, Moreira TR, Flor MJN. Multi-professional team's perception of nurses' competences in liver transplantations. Rev Bras Enferm. 2017;70(2):258-264. doi: 10.1590/0034-7167-2016-0223

22. Pinho NG, Viegas K, Caregnato RCA. [The role of the nurse along the perioperative period in order to prevent deep vein thrombosis]. Rev SOBECC [Internet]. 2016 [cited 2019 Jul 06];21(1):28-36. Available from: http://files.bvs.br/upload/S/14144425/2016/v21n1/a5572.pdf Portuguese.

23. Salgado-Filho MF, Morhy SS, Vasconcelos HD, Lineburguer EB, Papa FV, Botelho ESL. Consensus on Perioperative Transesophageal Echocardiography of the Brazilian Society of Anesthesiol2ogy and the Department of Cardiovascular Image of the Brazilian Society of Cardiology. Rev Bras Anestesiol. 2017;68(1):1-31. doi: 10.1016/j.bjane.2017.09.001

24. Romano ACL, Oliveira AAS. Surgical patient safety and patients human rights. Cad Ibero-Am Dir Sanit. 2017;6(3):232-251. doi: 10.17566/ ciads.v6i3.397

25. Prudente GFG, Pessoa GS, Ferreira SRR, Nunes NP, Bravo LG, Macena RHM, et al. [Physiotherapy in Liver Transplantation: Narrative and Integrative Revision]. UNOPAR Cient Ciênc Biol Saúde [Internet]. 2015 [cited 2019 Jul 06];17(1):51-5. Available from: http://www.pgss.com. br/revistacientifica/index.php/biologicas/article/view/1572

26. Oliveira RA, Turrini RNT, Poveda VB. Adherence to immunosuppressive therapy following liver transplantation: an integrative review. Rev Latino-Am Enfermagem. 2016;1(24):1-10. doi: 10.1590/1518-8345.1072.2778

27. Poveda VB, Nascimento AS. Intraoperative body temperature control: esophageal thermometer versus infrared tympanic thermometer. Rev Esc Enferm USP. 2016;50(6):945-50. doi: 10.1590/s0080-623420160000700010

28. Silva SG, Nascimento ERP, Hermida PMV, Sena AC, Klein TCR, Pinho FM. [Checklist for nur1 sing shift changes of patients in immediate post surgery to the admission in intensive care]. Enferm Foco [Internet]. 2016 [cited 2019 Jul 06];7(1):13-17. Available from: http://revista.cofen. gov.br/index.php/enfermagem/article/view/658/277 Portuguese.

29. Mandell MS, Lezotte D, Kam I, Zamudio S. Reduced use of intensive care after liver transplantation: patient attributes that determine early transfer to surgical wards. Liver Transplant. 2002;8(8):686-7. doi: 10.1053/jlts.2002.34380

30. Pires MOP, Pedreira MLG, Peterlini MAS. Cirurgia Segura em Pediatria: elaboração e validação de checklist de intervenção pré-operatórias. Rev Latino-Am Enfermagem [Internet]. 2013 [cited 2019 Jul 06];21(5):1-8. Available from: http://www.scielo.br/pdf/rlae/v21n5/pt_01041169-rlae-21-05-1080.pdf Portuguese.

31. Cucolo DF, Perroca MG. Instrument to assess the nursing care product: development and content validation. Rev Latino-Am Enfermagem. 2015;23(4):642-650. doi: 10.1590/0104-1169.0448.2599

32. Cruz IA, Selow MLC. [Assess the relevance of the safe surgery protocol in health institutions]. Rev Dom Acad [Internet]. 2017 [cited 2019 Jul 06];2(1):188-196. Available from: http://bit.ly/2JfJPMJ Portuguese.

33. Jonathan R Treadwell, Scott Lucas, Amy Y TsouSurgical checklists: a systematic review of impacts and implementation.BMJ Qual Saf. 2014;23(4):299-318. doi: 10.1136/bmjqs-2012-001797 